METALLURGY AND FOUNDRY ENGINEERING - Vol. 37, 2011, No. 1

Jadwiga Kamińska ${ }^{*}$ Joanna Kolczyk ${ }^{*}$, Sylwia Żymankowska-Kumon*

\title{
DEPENDENCE OF TENSILE WET STRENGTH FROM REGENERATION TIME AND GRAIN SIZE OF THE MATRIX CERAMIC MOULDS
}

\section{INTRODUCTION}

Multilayer ceramic moulds are used in the investment casting technology.

Shell, multi-layered moulds are used in an investment casting method. Production of ceramic moulds for investment casting by means of an investment casting method is based on a cyclic process of a wax model immersion in a liquid ceramic sand, powder topping with ceramic material of various grain coarseness followed by drying of the formed layer, until the required thickness and mechanical strength of the layered casting mould is obtained. At the end of this process the wax model is removed by melting. The quality of casting moulds as well as the quality of castings produced in such moulds strongly depends on a binding agent being a component of a liquid ceramic sand.

Binders and ceramic moulding sands prepared with them, should be characterised by several specific properties. The most important are listed below:

- homogeneity of a composition and a high stability of physical and chemical parameters in the determined time;

- good wettability of organic surfaces (wax or polymer models);

- no reactivity with materials of models;

- proper microstructure, facilitating a solvent vaporisation (shortening of mould drying times);

- appropriate mechanical strength and no susceptibility to deformations;

- high temperature resistance during annealing and pouring into moulds;

- no reactivity with metals during their pouring into moulds and cooling.

* M.Sc.: Faculty of Foundry Engineering, AGH University of Science and Technology, Kraków, Poland; e-mail: szk@agh.edu.pl 
The basic binding agent used in the investment casting for higher quality castings was - from the very beginning of the development of this method - hydrolysed ethyl silicate. On account of the regulations related to the environment protection attempts are undertaken to eliminate this kind of a binder and substituting it by a binding agent in which water is a solvent.

Hardening of a ceramic mould in a technology applying water solution of colloidal silica is mainly based on drying. The hardening process of thin ceramic layers is accelerated by an application of powder toppings, of a coarse matrix. This causes an external surface expansion, which significantly facilitates a water evaporation from colloidal silica.

A1

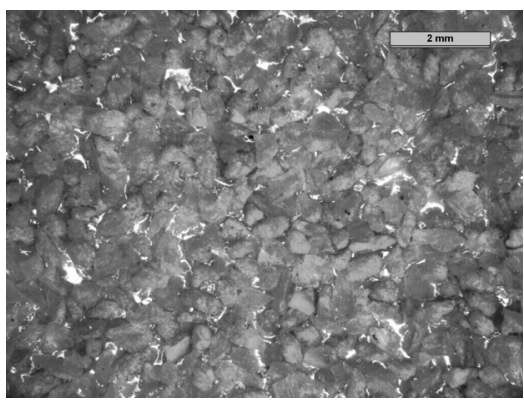

A2

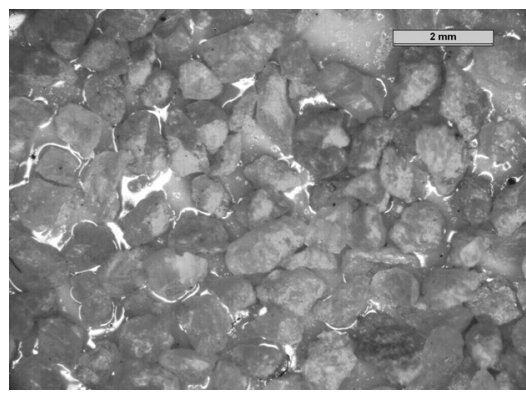

A3

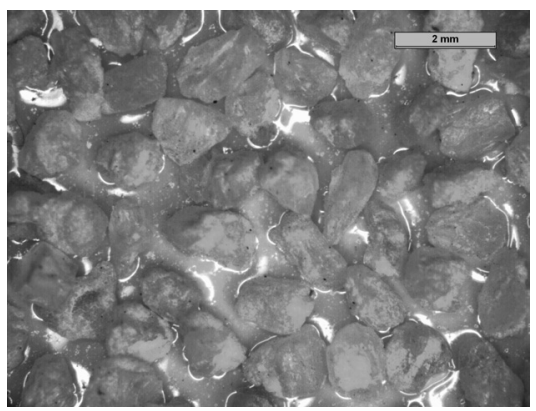

B1

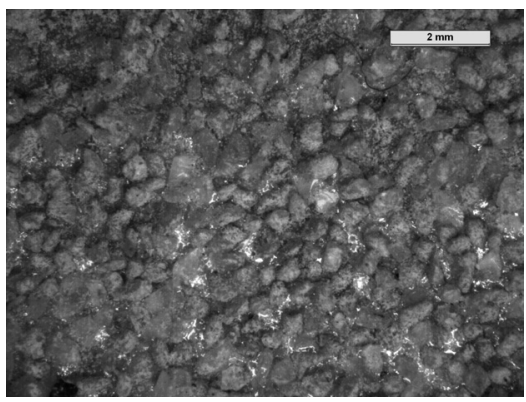

B2

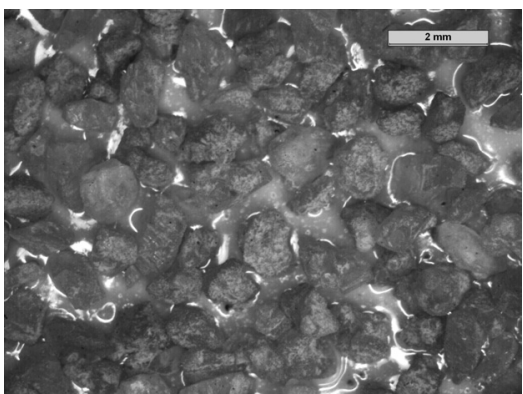

B3

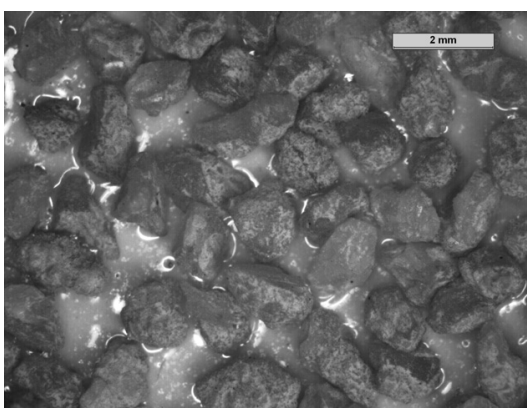

Fig. 1. Reclaimed sand: magnification $\times 20, A$ - time of the reclamation 5 min, $B$ - time of the reclamation $15 \mathrm{~min}, 1-d_{L}=0.2 \mathrm{~mm}, 2-d_{L}=0.4 \mathrm{~mm}, 3-d_{L}=0.63 \mathrm{~mm}$ 
The results of investigations concerning a determination of dependence between a size of grains used for powder toppings and a tensile strength under a wet condition are presented in this paper. Examinations were carried out with using fresh powder toppings and reclaimed materials from worn ceramic moulds.

The reclamation time was 5 and 15 minutes, respectively. The moulding sand, after the mechanical reclamation, was subjected to the sieve analysis in order to estimate the grain size $d_{L}$. The sieve analysis was done to fractionalise the reclaimed material into individual grain sizes. Separated grains of sizes: $0.2 ; 0.4$ and $0.63 \mathrm{~mm}$ were used for making layers of ceramic moulds (Fig. 1). Fresh and reclaimed ceramic powder toppings were applied as a matrix.

\section{INVESTIGATIONS}

The aim of the performed examinations was to determine an influence of grains used for powder toppings on the tensile strength under a wet condition. Reclaimed and fresh ceramic sands were used as the matrix of the mould. The fresh material of fractions: $d_{L}=0.2 ; 0.32$ and $0.73 \mathrm{~mm}$.

Worn ceramic moulds were crushed before the reclamation process. The reclamation process was carried out by means of the testing apparatus for the mechanical reclamation constructed in the Laboratory of Foundry Machines and Casting Design of the Faculty of Foundry Engineering, the University of Science and Technology, AGH in Krakow.

The reclaimed material, obtained after the reclamation process, was undergoing a sieve analysis and estimation of grain shapes. The sieve analysis was done to fractionalise the reclaimed material into individual grain sizes. The reclaimed material of fractions: $d_{L}=0.2 ; 0.4$ and $0.63 \mathrm{~mm}$ were applied in examinations. The matrix from spent moulds was obtained at the reclamation performed for 5 and 15 minutes.

Powder topping grains of the selected size were deposited on the metal core (divided sleeves), in order to determine its strength in wet condition.

\subsection{Methodology of preparing samples for measuring strength under wet conditions}

The core, which was used for making the mould layer undergoing rupture was of a roll - divided at a half of its length - shape. It was acting as a wax model, on which a multi-layer ceramic mould is being made. The sample with the deposited ceramic sand layer is shown in Figure 2. It is made in a few cycles: deposition of ceramic sand and powder topping with grain matrix.

Two coatings were deposited on the properly prepared sample. After each deposition of a ceramic sand a powder topping was placed on roll models. This powder was made of the reclaimed sands of the grain size: $d_{L}=0.2 ; 0.4$ and $0.63 \mathrm{~mm}$, respectively. In order to shorten a cooling time, sampled were dried under conditions of a forced air circulation. Samples were ruptured after 18 hours from depositing the second layer. 


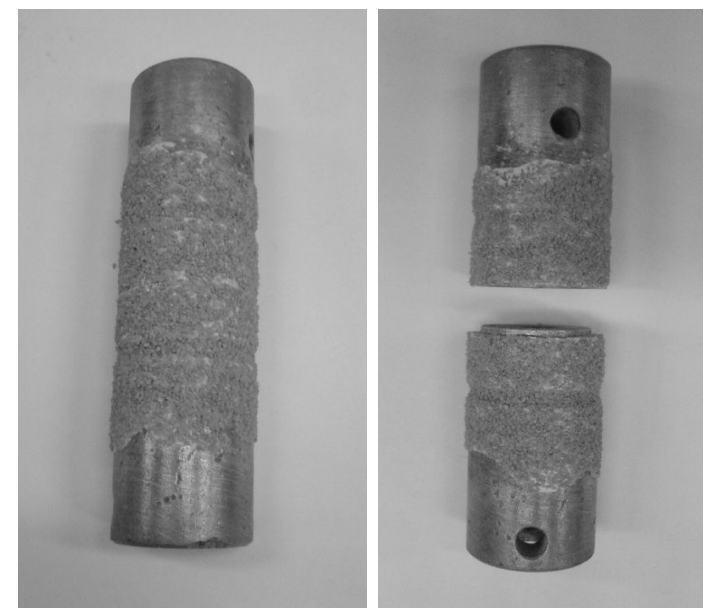

Fig. 2. Divided sample of a roll shape after deposition of the ceramic layer, before and after the rupture

\subsection{Tensile strength tests}

Tensile strength $R_{m}$ is determined as the ratio of the tensile force, which caused the sample rupture, to the initial cross-section of the sample, it means in the place of the smallest cross-section. Measurements were carried out on the universal equipment for testing strength of moulding sands. Sample of a roll shape with the deposited ceramic layer is being placed in special holders of the testing machine - during the measurements (Fig. 3). Clamping in the machine enables sample stretching in a vertical position.

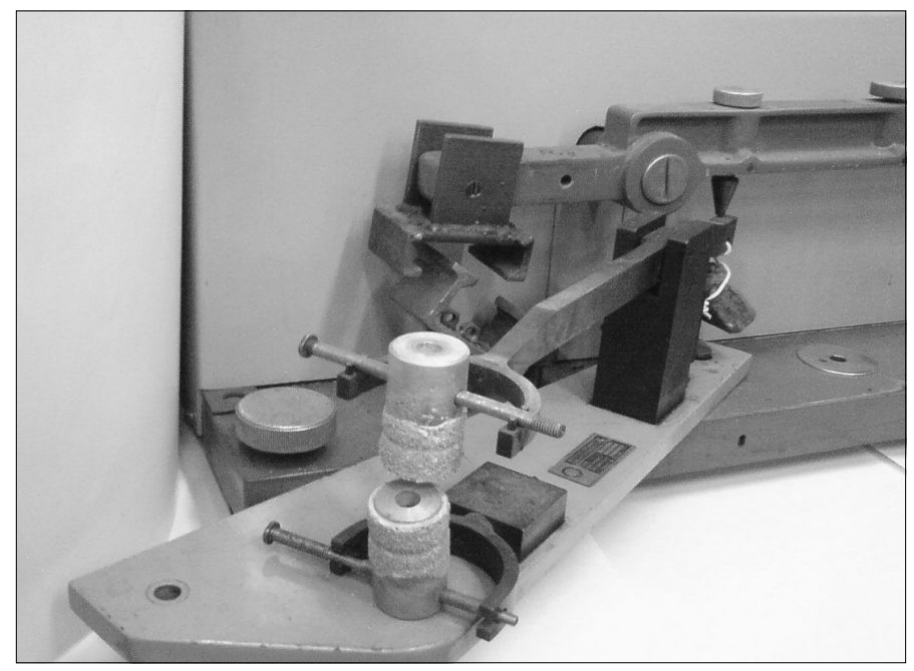

Fig. 3. Testing machine with a sample 
Operation of the compound lever causes that the upper and bottom part of the divided sleeve are pulled off from each other with increasing force up to a moment of a total rupturing of the ceramic layer. The obtained result is read from the scale. Then the area of the ceramic mould layer in the place of rupturing is measured. Stress values causing the sample rupturing is determined from the ratio of the force to the ruptured area of the stretched sample.

\section{OBTAINED RESULTS OF MOISTURE}

A moisture content of ceramic moulding sands significantly influences the ceramic mould strength. Investigations carried out previously indicate, that the moisture content decrease causes the mould strength increase. The pathways of drying of the reclaimed ceramic sands in dependence of the number of the deposited layers are presented in Figures. The water mass loss was measured by means of the thermobalance, used for the estimation of moisture contents in granular materials, including moulding sands and ceramic sands. After deposition of the ceramic sand layer, $5 \mathrm{~g}$ of sand was sampled (in some minutes intervals) from the divided sleeve to estimate its moisture content. The sample was placed in the thermobalance and dried at a temperature of $130{ }^{\circ} \mathrm{C}$. Successive measurements were made up to the moment of the sand wetness stabilization. Figures 4 and 5 present the drying history of the ceramic moulding sand prepared with using the matrix, after 5 minutes of reclamation, while Figures 6 and 7 - after 15 minutes. It is seen in the graphs that the ceramic sand moisture content for the first layer, both after 5 and 15 minutes of reclamation vary from $\sim 2.5 \%$ at the beginning of the drying process to $\sim 0.4 \%$ at the end of the process, while for the second layer from $\sim 7 \%$ to $\sim 2 \%$.

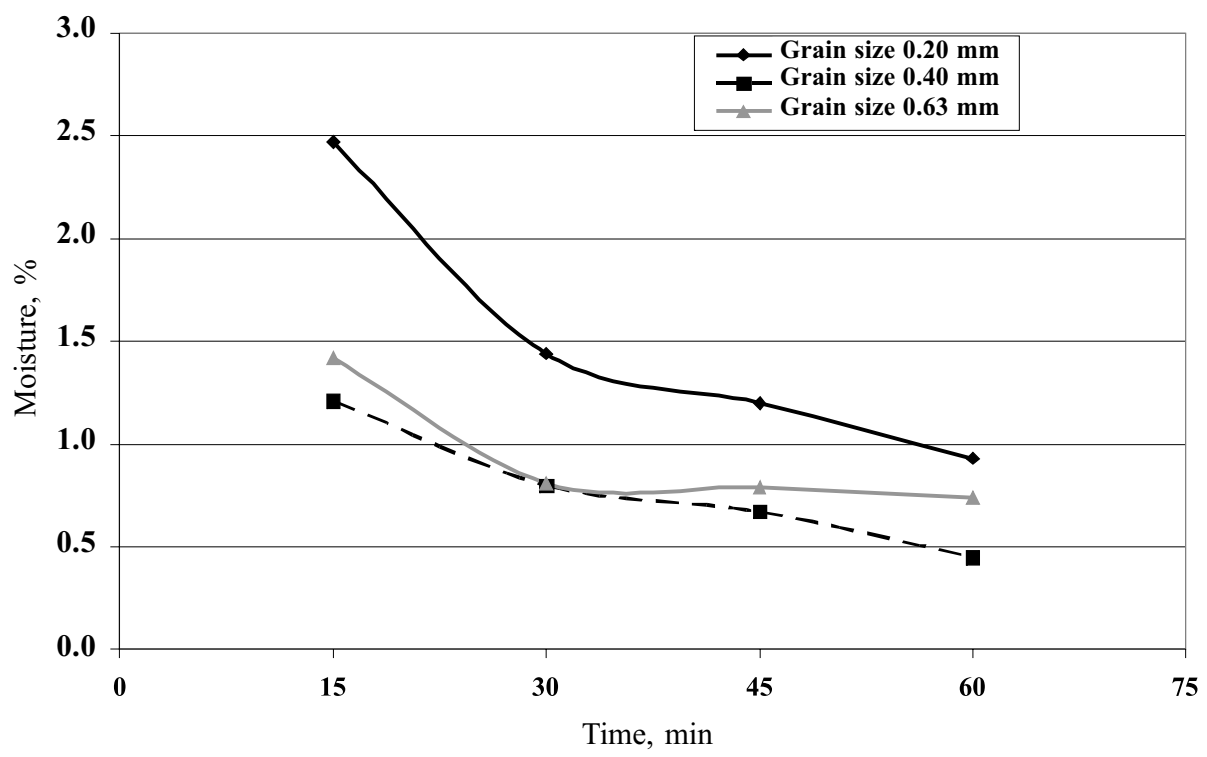

Fig. 4. Drying pathway of the $1^{\text {st }}$ layer of the ceramic sand made with the matrix obtained after 5 minutes of reclamation 


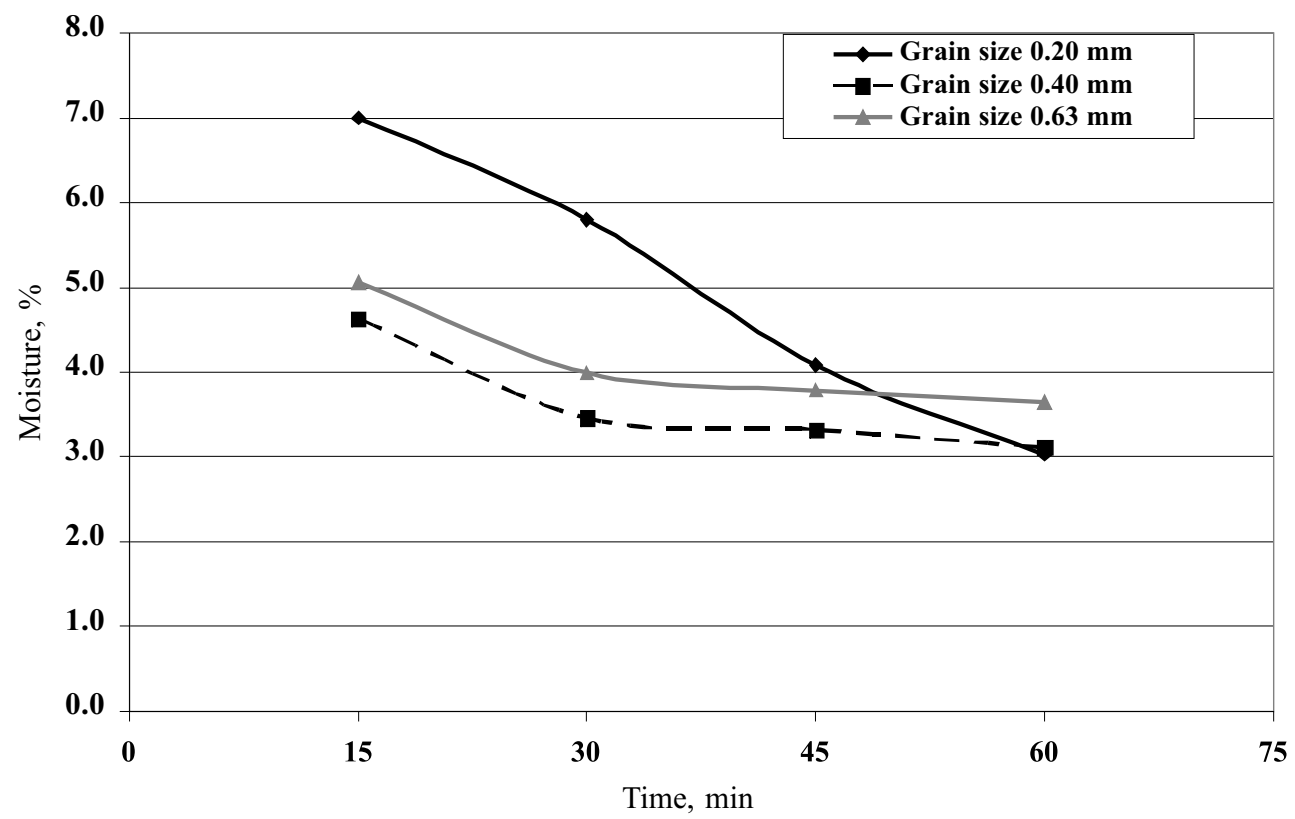

Fig. 5. Drying pathway of the $2^{\text {nd }}$ layer of the ceramic sand made with the matrix obtained after 5 minutes of reclamation

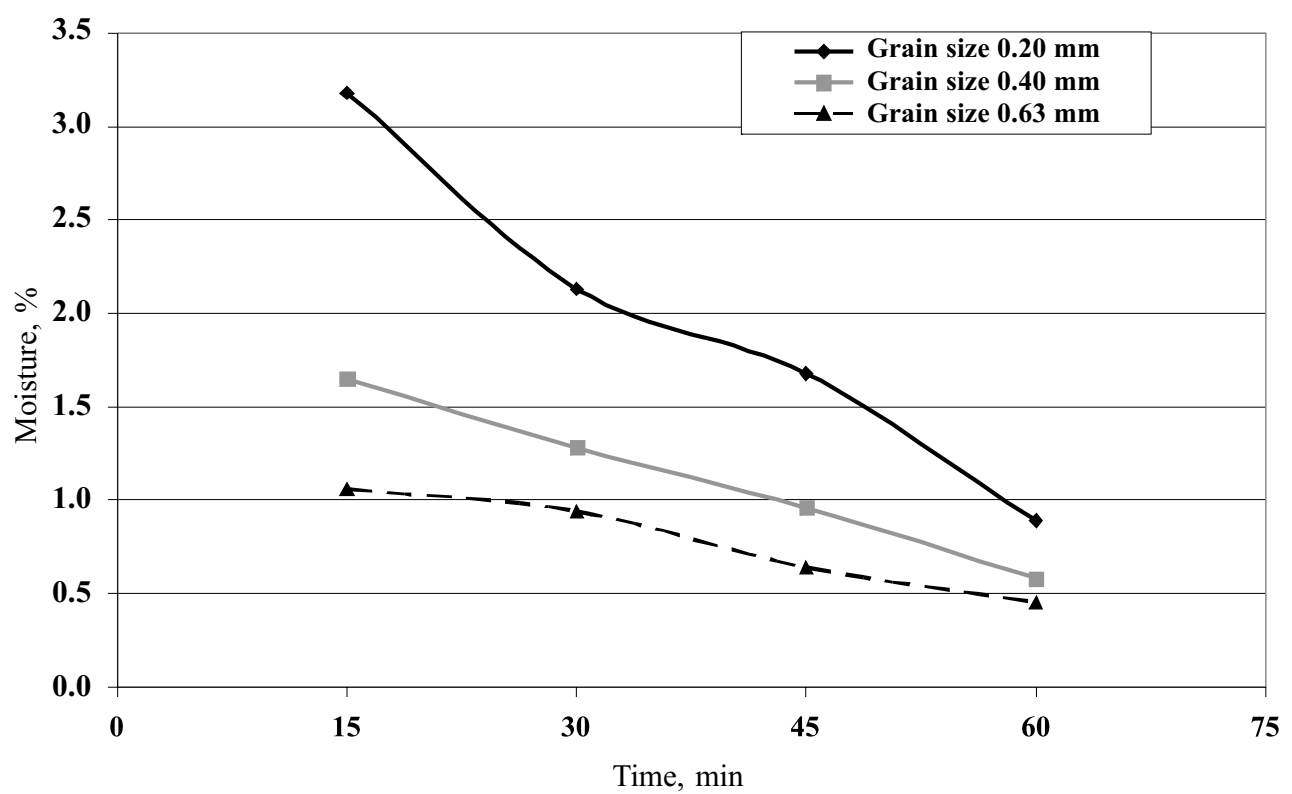

Fig. 6. Drying pathway of the $1^{\text {st }}$ layer of the ceramic sand made with the matrix obtained after 15 minutes of reclamation 


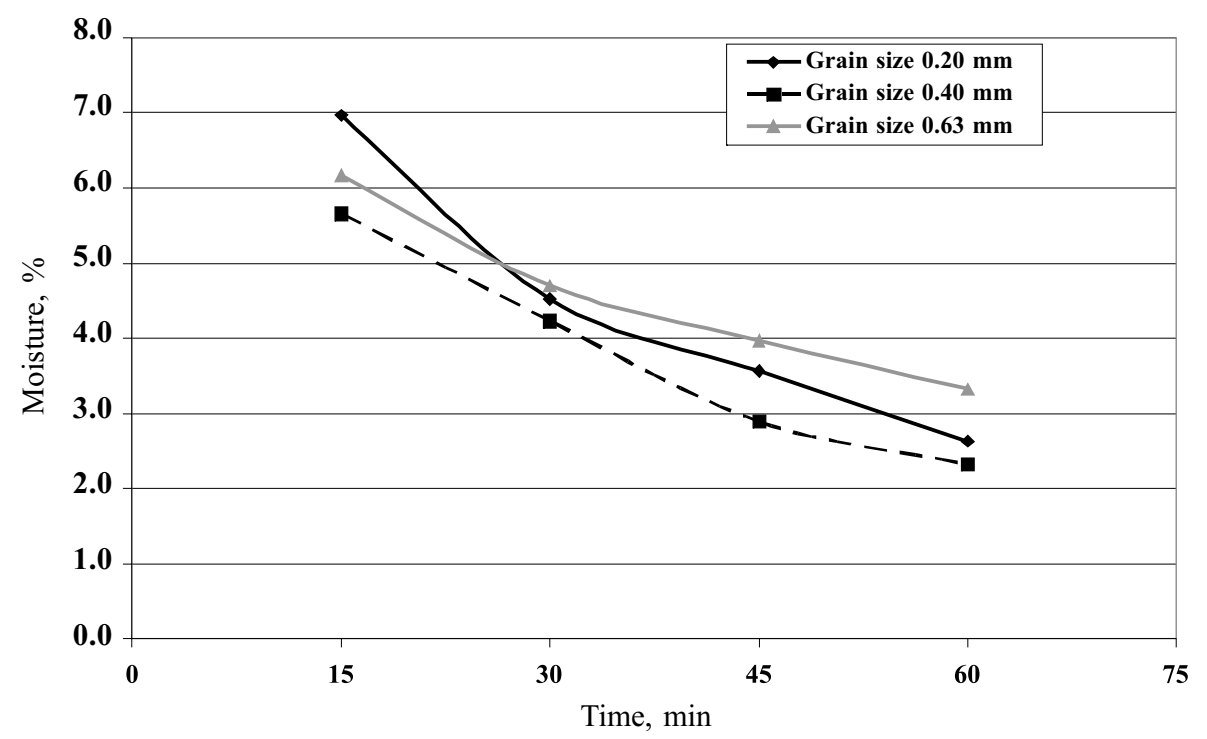

Fig. 7. Drying pathway of the $2^{\text {nd }}$ layer of the ceramic sand made with the matrix obtained after 15 minutes of reclamation

\section{OBTAINED RESULTS OF THE STRENGTH UNDER WET CONDITIONS: „GREEN STRENGTH”}

The results of the strength measurements in wet condition, of the ceramic moulds made out of fresh and out of the reclaimed ceramic moulding sand are shown in Figure 8.

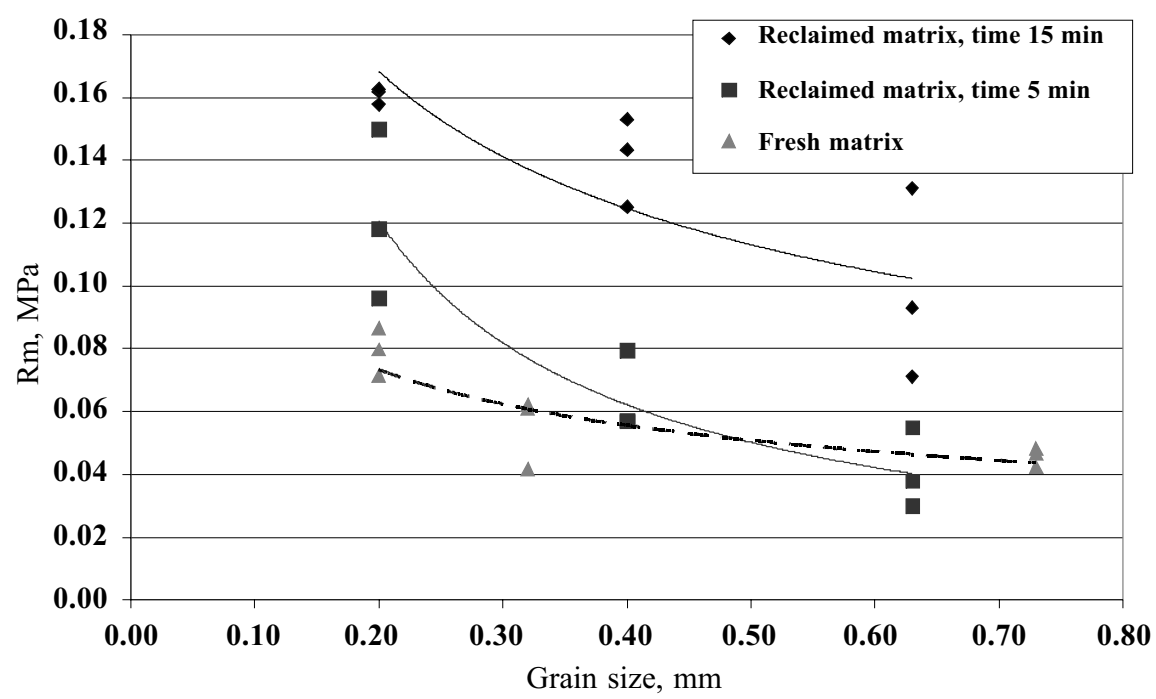

Fig. 8. Comparison of the grain size influence of the fresh and reclaimed matrix of the ceramic sand on the strength in wet condition 
It results from the graph that the grain size has a significant influence on the tensile strength in wet condition. Along with the grain size increase the strength decreases. Fine grains are characterized by a shape 'angularity', which in sands with chemical binders decrease their strength. However, Figure 9 indicates that this dependence is not found in multilayer cera-mic moulds used in the investment casting technology. The matrix obtained after the prolonged reclamation time allows to produce moulds of a higher strength $R_{m}$.

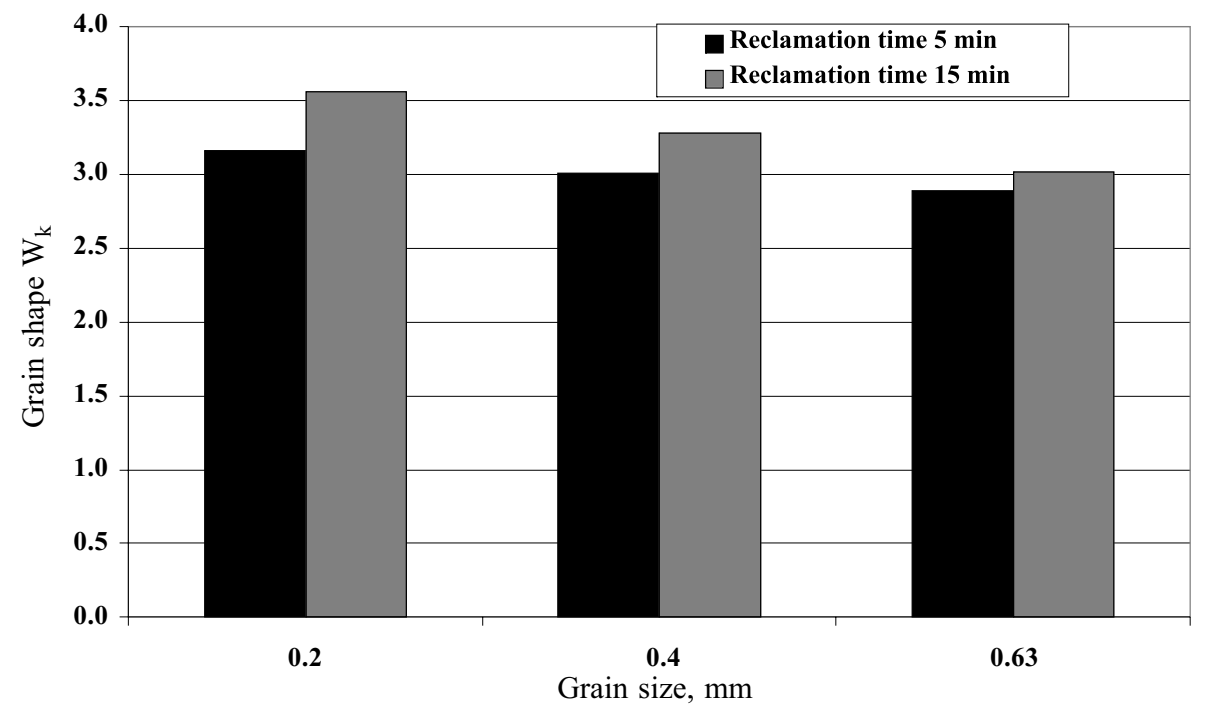

Fig. 9. Indicator of the reclaimer grain shape

\section{CONCLUSIONS}

The influence of the ceramic matrix grain size (colloquially called a powder topping) on the strength of moulds applied in the investment casting technology - was determined.

The actual strength of the ceramic mould depends on the strength of individual layers, thus - in fact - on the grain size.

The strength under wet conditions decreases when the matrix grain size increases. The strength for fresh matrix grain size decreases by approximately $30 \%$ at $d_{L}$ increased from $0.20 \mathrm{~mm}$ to $0.73 \mathrm{~mm}$. The strength for reclaimed matrix grain size decreases by approximately $70 \%$ at $d_{L}$ increased from $0.20 \mathrm{~mm}$ to $0.63 \mathrm{~mm}$. In case of the moulding sand prepared with the matrix - being after 5 minutes of the reclamation process - the strength decreases by app. $70 \%$ when $d_{L}$ increases from $0.20 \mathrm{~mm}$ to $0.63 \mathrm{~mm}$, whereas when the matrix was after 15 minutes of the reclamation process this decrease equalled app. $35 \%$.

The differences are probably due to different grain shapes.

\section{Acknowledgements}

The study was performed within the Research Project MNiSW No. N507320440 (2011-2012) 


\section{REFERENCES}

[1] Dańko R., Kamińska J.: Assessment of the reclamation of used sands from the alpha-set technology in the testing apparatus, Archives of Foundry Engineering, 9 (2009) 1, 33-37

[2] Holtzer M.: Materiały II Sympozjum Naukowego Wykonawców PBZ-MNiSW-03///2007, Rzeszów, 15-16.12.2009 (not published)

[3] Kamińska J., Kolczyk J., Żymankowska-Kumon S.: Wpływ wielkości ziarna regeneratu form ceramicznych stosowanych w technologii wytapianych modeli na ich wytrzymałość w stanie na wilgotno, Sesje Studenckich Kół Naukowych, Materiały XLVII Sesji Pionu Hutniczego, 1/2010 Kraków

[4] Kamińska J., Kolczyk J., Żymankowska-Kumon S.: Effect of grain size of the reclaimed ceramic moulds used in the lost wax technology on the strength at high temperature, 13th International Symposium of Students and Young Mechanical Engineers „Advances in Chemical and Mechanical Engineering”, Gdańsk 2010, pp. 192-197

[5] Kamińska J., Kolczyk J., Żymankowska-Kumon S.: Effect of grain size of the reclaimed matrix ceramic moulds used in the lost wax technology on the strength at high temperature, Metallurgy and Foundry Engineering, 36 (2010) 1, 31-35

[6] Lewandowski J.L.: Materiały formierskie. Laboratorium, Wydawnictwo AGH, Kraków, 1997

[7] Lewandowski J.L.: Tworzywa na formy odlewnicze, Wyd. Nauk. „Akapit” Kraków, 1997

[8] Sarek D.: Opracowanie metodyki badania właściwości technologicznych nowych, ekologicznych tworzyw stosowanych na formy ceramiczne w WSK „PZL-Rzeszów” S.A., AGH, Kraków, 2005 (praca magisterska, niepublikowana)

[9] Zych J.: Koncepcja badania wytrzymałości powłok ceramicznych stosowanych w technologii pełnej form i wytapianych modeli, Wydawnictwo XII Międzynarodowa Konferencja Naukowo-Techniczna Odlewnictwa Metali Nieżelaznych, Iwonicz, 4-6 czerwca 2009 